\title{
GMR
}

\section{Fis linte}

\section{Identification and evaluation of polymorphisms in FABP3 and FABP4 in beef cattle}

\author{
I.M.Z. Blecha', F. Siqueira², A.B.R. Ferreira², G.L.D. Feijón', R.A.A. Torres Junior², \\ S.R. Medeiros ${ }^{2}$, I.I. Sousa ${ }^{3}$, G.G. Santiago ${ }^{4}$ and A.L.J. Ferraz ${ }^{1}$ \\ ${ }^{1}$ Universidade Estadual de Mato Grosso do Sul, Aquidauana, MS, Brasil \\ ${ }^{2}$ Embrapa Gado de Corte, Campo Grande, MS, Brasil \\ 3Universidade Anhanguera Uniderp, Campo Grande, MS, Brasil \\ ${ }^{4}$ Universidade Federal de Mato Grosso do Sul, Campo Grande, MS, Brasil \\ Corresponding author: F. Siqueira \\ E-mail: fabiane.siqueira@embrapa.br
}

Genet. Mol. Res. 14 (4): 16353-16363 (2015)

Received August 15, 2015

Accepted October 6, 2015

Published December 9, 2015

DOI http://dx.doi.org/10.4238/2015.December.9.3

ABSTRACT. Single nucleotide polymorphisms (SNPs) were screened in FABP3 and FABP4 by automatic sequencing of pools of DNA from crossbred animals whose phenotypes belonged to the upper and lower extremes for back fat and marbling, as well as of a pool of DNA from sires used for crossbreeding. Five SNPs were identified in FABP3 and another nine SNPs were identified in FAPB4. Of these, only one SNP had no previous registry in the SNAP database (dbSNP). Three polymorphisms were selected for further evaluation of their association with production traits using restriction fragment length polymorphism-PCR (RFLP-PCR) or real-time PCR genotyping. All 3 markers were in Hardy-Weinberg equilibrium at the $5 \%$ significance level for all 7 genetic groups analyzed. Significant association was observed between FABP3-G/A with rib eye area $(P=0.035)$ and the rib eye area/hot carcass weight ratio $(P=0.025)$ and between $F A B P 4 /$ Tasl with marbling $(P=0.052)$ and meat texture $(P$ $=0.053)$. No significant association was observed between the FABP4$G / C$ polymorphism and any of the observed traits. Previous association studies with allelic variants in these genes have shown mixed results, 
probably because of the small effect of the genes for these traits, which suggests that results should be replicated in other populations.

Key words: A-FABP; Ribeye area; Back fat; $H-F A B P$; Molecular marker; Marbling

\section{INTRODUCTION}

The beef cattle industry in Brazil has undergone intense transformation in response to increasing demands for a better quality product. Traits such as back and intramuscular fat deposition in beef cattle directly influence the choice of the consumer for succulence, taste, and tenderness (Luchiari Filho, 2000). Classic genetic animal improvement has given way to changes in the genetic composition of populations through selection and a breeding system intended to increase the frequency of favorable alleles and provide production increments along with improvement in traits of commercial interest (Euclides Filho, 1999; Ferraz and Eler, 2010).

Some traits, however, are tricky to improve upon by classic animal improvement, mainly when they present low heritability or are cumbersome or are measured at a late age (Davis and DeNise, 1998; Van Eenennaam, 2009). In these situations, marker assisted selection (MAS) complements traditional methods, allowing the selection of animals at an early age and with higher accuracy.

The identification of candidate genes responsible for phenotypic variations has been a challenge, mostly because of the quantitative nature of these variables; in other words, because they are controlled by many genes and are affected by the environment (Andersson, 2001). Several candidate genes have been identified and associated with carcass quality and fat deposition traits, such as TG (Barendse, 1999), LEP (Buchanan et al., 2002), DGAT1 (Thaller et al., 2003), genes in the FABP (fatty acid-binding proteins) family, which encode small, highly conserved, cytoplasmic proteins that bind to long chain fatty acids and other hydrophobic ligands (Roy et al., 2003; Chmurzynska, 2006; Michal et al., 2006), and others.

The heart type FABP3 protein is present in several tissues with a high demand of fatty acids such as cardiac and skeletal muscle and lactating mammary gland. FABP3 gene is involved in fatty acid transport from the cell membrane to intracellular sites (Veerkamp and Maatman, 1995; Roy et al., 2003). Fatty acid binding protein 4 (FABP4) is expressed in adipose tissue and plays an important role in lipid metabolism and homeostasis in adipocytes. FABP4 gene has been shown to be associated with lipid metabolism (lipolysis and lipogenesis), marbling, and back fat deposition (Specht et al., 1996; Hertzel et al., 2006; Michal et al., 2006).

Therefore, our objective was therefore to identify single nucleotide polymorphisms (SNPs) in $F A B P 3$ and FABP4 by automatic sequencing, estimate allelic and genotypic frequencies, and evaluate association with meat and carcass quality traits in beef cattle.

\section{MATERIAL AND METHODS}

The experiment was carried out at Embrapa Gado de Corte, in Campo Grande, Mato Grosso do Sul (MS), Brazil, at the geographical coordinates $20^{\circ} 27^{\prime} \mathrm{S}$ and $54^{\circ} 37^{\prime} \mathrm{W}$, and at an altitude of $530 \mathrm{~m}$. The climate in this region is classified as tropical savanna and characterized by a well-defined dry period during the colder months and a rainy period during the summer months.

The production of experimental animals, maintenance, slaughter and harvesting of biological samples were performed as required by Brazilian Law No. 11.794 of October 8, 2008 
and as by other rules applicable to the use of animals for scientific purposes, especially Normative Resolutions of National Council for Animal Experiments Control (CONCEA) and the Brazilian Guideline for Care and Use of Animals for Scientific and Teaching Purposes (DBCA).

Super-precocious steers evaluated in this work were obtained from the crossbreeding of $501 / 2$ Valdostana $+1 / 2$ Nelore (VN) cows, $501 / 2$ Angus $+1 / 2$ Nelore (AN) cows and $801 / 2$ Caracu $+1 / 2$ Nelore (CN) cows. Breeding between maternal and terminal breeds was carried out between VN and AN cows inseminated by Caracu (CR) sires [yielding $75 \%$ taurine and $75 \%$ adapted (CRVN and CRAN) calves] and Canchim (CC) sires [yielding 56.25\% taurine and $43.75 \%$ adapted (CCVN and CCAN) calves]. In parallel, CN cows were inseminated by Caracu sires [yielding $75 \%$ taurine and $100 \%$ adapted (CRCN) calves], by Canchim sires [yielding $56.25 \%$ taurine and $68.75 \%$ adapted (CCCN) calves], and by Angus sires [yielding 75\% taurine and 50\% adapted (RACN) calves]. In total, 201 calves divided into 7 genetic groups were obtained.

Male and female calves were weaned at 240 days, submitted to confinement in individual pens, and fed a diet based on sorghum, corn, and soybean meal fodder with and without the addition of cottonseeds and soybean hulls. During the experiment, animals were observed every 28 days for weighing and for taking ultrasound measurements of the longissimus dorsi muscle area (rib eye area, REA) and back fat (BF) thickness in the dorsal-lumbar region, between the 12 th and 13th ribs. Animals were slaughtered when they reached a minimum of $5 \mathrm{~mm}$ of $\mathrm{BF}$, thus determining the variable of days in confinement (DCONF).

Measurements of slaughter weight (SW), hot carcass weight $(\mathrm{HCW})$, and dressing percentage (the ratio between SW and $\mathrm{HCW}=$ dress \%) were taken at the time of slaughter. Twenty-four hours after slaughter, the longissimus dorsi muscle was analyzed between the 12th and 13th ribs of the right half-carcass. The measurements taken included carcass fat thickness (CFT), REA, marbling (MARB), physiological maturity (FISMAT), and texture (TEXT), as proposed by Muller (1980). Samples were also collected from the longissimus dorsi muscle for analysis of tenderness based on shear force (SF) measured in a Warner-Bratzler instrument as described by Menezes et al. (2009).

For genotyping, blood samples were collected from 201 animals into $4.5 \mathrm{~mL}$ vacutainer tubes containing K3 EDTA, and semen was collected from sires used for breeding. Genomic DNA was extracted by the method described by Regitano and Coutinho (2001). DNA was quantified on a NanoDrop spectrophotometer (Thermo Fisher Scientific Inc, Wilmington, DE, USA) and integrity was verified by electrophoresis on a $0.8 \%$ agarose gel.

Pools containing DNA from 14 animals each were created in order to screen for SNPs in $F A B P 3$ and FABP4. The animals in each pool were balanced with respect to gender and genealogy, and they represented the upper and lower extremes for marbling and back fat. In order to determine the maternal or paternal origin of the SNPs, an extra pool containing DNA from the 18 sires that were used for crossbreeding was created. All pools were prepared in duplicate and contained 200 ng of DNA from each animal to minimize variation in composition and concentration.

Oligonucleotide pairs (Table 1) were designed to amplify regions of interest in sequences from FABP3 and FABP4 available in GenBank (www.ncbi.nlm.nih.gov) under Accession Nos. 281758 and 281759 , respectively. The oligonucleotides used for sequence amplification flanked all exons and spanned both untranslated regions (UTRs) and parts of the intronic regions. These were designed using Primer 3 plus software available online (http://frodo.wi.mit.edu/primer3/) and specificity was verified using OligoAnalyzer v. 3.1, also available online (http://www.idtdna.com/ analyzer/Applications/OligoAnalyzer/). 
Table 1. Forward and reverse oligonucleotide sequences, and the size of each amplicon used to amplify regions of interest in sequences of $F A B P 3$ and FABP4 in beef cattle.

\begin{tabular}{lcllc}
\hline Gene & Fragment & Forward $\left(5^{\prime}-3^{\prime}\right)$ & Reverse $\left(5^{\prime}-3^{\prime}\right)$ & Amplicon (bp) \\
\hline FABP3 & 1 & GTGACACAGGGGCCTTTTA & GGGAACCAAGATCCCACAT & 425 \\
FABP3 & 2 & CTCTTCTCCCTCCCCAACAT & CCCACACAGGCAACAGGTAGAT & 481 \\
FABP3 & 3 & TCTGGCTCTCACACCATCAG & TGCAAGCACTCTCTCCTTCA & 519 \\
FABP3 & 4 & CTGTCAAGAACCTGGCACAT & TGCTTCCTGAGTAGCAGTCTTT & 564 \\
FABP4 & 1 & AAAAAGAGGCAGAAAGCCAAG & CAGAGGGAAAACTGCAGAGG & 510 \\
FABP4 & 2 & ATGGAATGCTTTCCTCCTT & TTGTGCCTTGGGTTTCTTT & 443 \\
FABP4 & 3 & CAAGGGCGATTGTCTCTATTTCTC & CCCCTATGATGCTATTCCACA & 548 \\
FABP4 & 4 & TCCCTGAGAGGGTGTTTTT & CCTGCTCAACATTGAAGGAGAC & \\
\hline
\end{tabular}

$\mathrm{PCR}$ reactions were carried out in $25 \mu \mathrm{L}$ reactions containing $80 \mathrm{ng}$ genomic DNA, 0.164 $\mu \mathrm{M}$ each oligonucleotide, $10 \mathrm{mM}$ Tris- $\mathrm{HCl}, \mathrm{pH} 8.0,50 \mathrm{mM} \mathrm{KCl}, 2.0 \mathrm{mM} \mathrm{MgCl}, 0.2 \mathrm{mM}$ each dNTP, and 0.65 units (U) Taq DNA polymerase (Invitrogen ${ }^{\mathrm{TM}}$ ). PCR reactions were submitted to $2 \mathrm{~min}$ at $95^{\circ} \mathrm{C}$ for initial denaturing followed by 35 cycles of $94^{\circ} \mathrm{C}$ for $30 \mathrm{~s}, 60^{\circ} \mathrm{C}$ for $30 \mathrm{~s}$, and $72^{\circ} \mathrm{C}$ for $30 \mathrm{~s}$. A final extension step at $72^{\circ} \mathrm{C}$ for 5 min was also included.

PCR products were purified using Exonuclease I (Exol, USB Products) and shrimp alkaline phosphatase (SAP, USB Products) and submitted to a sequencing reaction using a BigDye ${ }^{\circledR}$ Terminator Cycle Sequencing Kit (v.3.1, Applied Biosystems, Foster City CA, USA). Automatic sequencing was carried out in an $\mathrm{ABI} 3130$ instrument (Applied Biosystems). Each pool was sequenced using both the forward and reverse oligonucleotides separately and all reactions were carried out in duplicate.

SNP detection was carried out using CodonCode Aligner software (CodonCode Corporation, www.codoncode.com). Forward and reverse duplicate sequences were aligned for each pool generating a consensus sequence per pool. Consensus sequences were then compared among all pools generating a consensus sequence for all pools, which was then aligned to the Bos taurus taurus reference genome sequence obtained from NCBI.

Three of the 14 identified SNPs were selected and genotyped in 201 animals individually and their association with traits of interests was analyzed. Criteria for selection of SNPs included confirmation in duplicate pools, association to beef quality traits in previous studies, localization within the gene, and no previous identification in the SNP database (dbSNP; http://www.ncbi.nlm. nih.gov/projects/SNP/) or in the literature. Two of these SNPs were located on FABP4 and identified herein as FABP4/Tasl (rs109346428) and FABP4-G/C (rs110383592). The third SNP, which was identified in FABP3 (FABP3-G/A), had no previous registry in dbSNP.

The FABP4/TasI SNP was genotyped using restriction length fragment polymorphism-PCR (RFLP-PCR) since it was located within the restriction site of endonuclease Tasl (Tsp509I). The forward and reverse oligonucleotides used for PCR were 5'-ATTATCCCCACAGAGCATCG-3' and 5'-TACTGCTGGGGGCACAGTAT-3', respectively, generating a 297-bp fragment. PCR was carried out in a final reaction volume of $25 \mu \mathrm{L}$ containing $120 \mathrm{ng}$ DNA, $0.164 \mu \mathrm{M}$ each oligonucleotide, 10 $\mathrm{mM}$ Tris- $\mathrm{HCl}, \mathrm{pH} 8.0,50 \mathrm{mM} \mathrm{KCl}, 3.0 \mathrm{mM} \mathrm{MgCl}_{2}, 0.2 \mathrm{mM}$ each dNTP, $1.0 \mathrm{U}$ Taq DNA polymerase and submitted to the following program: $5 \mathrm{~min}$ for initial denaturing at $95^{\circ} \mathrm{C}$, followed by 30 cycles at $94^{\circ} \mathrm{C}$ for $30 \mathrm{~s}, 63^{\circ} \mathrm{C}$ for $30 \mathrm{~s}$, and $72^{\circ} \mathrm{C}$ for $30 \mathrm{~s}$. Reactions were terminated after a final extension step at $72^{\circ} \mathrm{C}$ for $7 \mathrm{~min}$.

Amplicons were digested in a reaction containing $7 \mu \mathrm{L}$ PCR product and $1 \mathrm{U}$ Tasl restriction enzyme. Reactions were incubated at $65^{\circ} \mathrm{C}$ for $3 \mathrm{~h}$. Resulting fragments were separated on $3 \%$ agarose gels and stained with SybrGold (1:50,000). Gels were observed and photographed 
by exposure to ultraviolet light. Two individuals belonging to each genotype were submitted to automatic sequencing to confirm the RFLP-PCR results. The GG genotype was characterized by the presence of 3 restriction fragments $(136,114$, and $47 \mathrm{bp})$ and the AA genotype by 4 restriction fragments $(136,83,47$, and $31 \mathrm{bp})$. Heterozygous animals (GA) presented 5 fragments. The 136and 47-bp fragments were common to all genotypes and were considered positive controls for efficient Tasl cleavage.

The other two selected SNPs (FABP3-G/A and FABP4-G/C) were genotyped by real-time PCR using TaqMan. Oligonucleotide and reporter sequences are detailed in Table 2, and they were used at concentrations of 36 and $8 \mu \mathrm{M}$, respectively. Genotyping was carried out in the Step One Plus instrument (Applied Biosystems). Reactions were carried out in a final volume of $5 \mu \mathrm{L}$ containing $30 \mathrm{ng}$ DNA, $2.5 \mu \mathrm{L}$ TaqMan Master Mix, and $0.125 \mu \mathrm{L}$ TaqMan assay. All PCR reaction plates contained positive controls for each possible genotype to facilitate grouping of tested samples and negative controls containing water in place of DNA.

Genotypic and allelic frequencies were calculated according to Weir (1996) and HardyWeinberg equilibrium was verified using the chi-square test. Discrepancies between expected and observed frequencies were analyzed at $5 \%$ significance.

Association studies were carried out using analysis of variance for traits related to beef and carcass quality using the general linear model (GLM) in the SAS statistical program (SAS Institute, 2003). The model considered the effect of each genotype on the polymorphism, year of birth (season), cattle lot (according to season of birth), sex, diet, genetic group of the individual, the sire, and the cow.

When significant effects ( $P \leq 0.05$ ) were observed for the genotype, allelic substitution was estimated by substituting the effect of the genotype in the statistical model by co-variables representing the least frequent allele $(0,1$, and 2$)$.

Table 2. Oligonucleotide and reporter sequences used in real-time PCR to genotype two single nucleotide polymorphisms (SNPs) in FABP3 and FABP4 in beef cattle.

\begin{tabular}{lllll}
\hline Gene & Forward & Reverse & Reporter 1 & Reporter 2 \\
\hline FABP3 & GGTCATTGAGCCCCTTGTACT & GAGGGAAGGGTATGAGCATGAG & TCGCCTCTCGCTCCAG (VIC) & TCGCCTCTCACTCCAG (FAM) \\
FABP4 & TGGGATGACCTAGCACTAAAATCTAGAA & ACCATAAAGAGAAAACTCGTGGATGAT & AGAAGATACTCACGAGCACC (VIC) & AGAAGATACTCACCAGCACC (FAM) \\
\hline
\end{tabular}

VIC and FAM: fluorophores used to label SNP nucleotides.

\section{RESULTS}

The SNPs identified in FABP3 and FABP4 can be found in Table 3. Five SNPs were identified within FABP3, 4 of which had previously been deposited in dbSNP, and 1 of which is described in this study for this first time. This SNP was deposited in GenBank in November 2014 and it is available under acession No. KM 382065.1 (www.ncbi.nlm.nih.gov/nuccore/KM382065). In FABP4, 9 SNPs, all of which had previously been described and deposited in dbSNP, were identified. Three of the 9 SNPs in FABP4 were located in the 3'UTR. A large number of observed SNPs were found in intronic regions.

After genotyping all 201 animals, both allelic variants from all 3 SNPs were found to be represented in the seven genetic groups studied. The allelic frequencies for the FABP3-G/A, FABP4-G/C and FABP4/Tasl polymorphisms within each of the seven genetic groups can be found in Table 4. For the FABP3-G/A SNP, the G allele was the most frequent in all genetic groups. 
Groups RACN, CRAN, CRCN, and CRVN presented the highest frequencies of this allele at an average of $81.58 \%$, while all other groups presented an average of $66.33 \%$. For FABP4-G/C, the C allele was the most frequent and the groups with the highest frequencies for this allele were CCCN, RACN, and CCAN with an average of $86.80 \%$, while in other groups this allele averaged $70.65 \%$. The $\mathrm{G}$ allele was the most frequent for FABP4/Tasl and the groups with the highest frequency of this allele were CCVN, CRAN, CRCN and CRVN with an average of $57 \%$, while the other groups averaged $44.3 \%$.

\begin{tabular}{|c|c|c|c|}
\hline Gene & SNP & Localization & dbSNP accession No. \\
\hline FABP3 & C/G & INTRON I & rs210186725 \\
\hline FABP3 & $\mathrm{G} / \mathrm{A}$ & INTRON I & Not previously deposited \\
\hline FABP3 & $\mathrm{A} / \mathrm{G}$ & INTRON III & rs109315289 \\
\hline FABP3 & $\mathrm{A} / \mathrm{G}$ & INTRON III & rs209338531 \\
\hline FABP3 & $\mathrm{C} / \mathrm{T}$ & INTRON III & rs210785101 \\
\hline FABP4 & $\mathrm{G} / \mathrm{T}$ & INTRON II & rs134173517 \\
\hline FABP4 & $\mathrm{A} / \mathrm{T}$ & INTRON II & rs109014985 \\
\hline FABP4 & C/G & EXON III & rs 110383592 \\
\hline FABP4 & $\mathrm{A} / \mathrm{G}$ & INTRON III & rs109388335 \\
\hline FABP4 & $\mathrm{A} / \mathrm{G}$ & INTRON III & rs109346428 \\
\hline FABP4 & $\mathrm{C} / \mathrm{T}$ & EXON IV & rs 110370032 \\
\hline FABP4 & $\mathrm{A} / \mathrm{G}$ & 3'UTR & rs109077068 \\
\hline FABP4 & $\mathrm{C} / \mathrm{T}$ & 3'UTR & rs110266999 \\
\hline FABP4 & $\mathrm{C} / \mathrm{G}$ & 3'UTR & rs109593774 \\
\hline
\end{tabular}

Table 4. Allelic frequencies for the FABP3-G/A, FABP4-G/C, and FABP4/Tasl polymorphisms within each of the seven genetic groups and for the total population of beef cattle.

\begin{tabular}{lccccccccc}
\hline Marker & Allele & \multicolumn{7}{c}{ Genetic groups } & Total (N = 201) \\
\cline { 2 - 9 } & & $\begin{array}{c}\text { CCAN } \\
(\mathrm{N}=26)\end{array}$ & $\begin{array}{c}\text { CCCN } \\
(\mathrm{N}=32)\end{array}$ & $\begin{array}{c}\text { CCVN } \\
(\mathrm{N}=25)\end{array}$ & $\begin{array}{c}\text { CRAN } \\
(\mathrm{N}=29)\end{array}$ & $\begin{array}{c}\text { CRCN } \\
(\mathrm{N}=28)\end{array}$ & $\begin{array}{c}\text { CRVN } \\
(\mathrm{N}=26)\end{array}$ & $\begin{array}{c}\text { RACN } \\
(\mathrm{N}=35)\end{array}$ \\
\hline FABP3-G/A* & $\mathrm{G}$ & 65.4 & 65.6 & 68.0 & 82.8 & 80.4 & 78.8 & 84.3 & 75.4 \\
& $\mathrm{~A}$ & 34.6 & 34.4 & 32.0 & 17.2 & 19.6 & 21.2 & 15.7 & 24.6 \\
FABP4- G/C* & $\mathrm{C}$ & 80.8 & 95.3 & 68.0 & 72.4 & 76.8 & 65.4 & 84.3 & 80.0 \\
& $\mathrm{G}$ & 19.2 & 4.7 & 32.0 & 25.6 & 23.2 & 34.6 & 15.7 & 20.0 \\
FABP4/TasI & $\mathrm{G}$ & 46.2 & 43.8 & 60.0 & 51.7 & 57.1 & 61.5 & 42.9 & 51.2 \\
& $\mathrm{~A}$ & 53.9 & 56.3 & 40.0 & 48.3 & 42.9 & 38.5 & 57.1 & 48.8 \\
\hline
\end{tabular}

*Significant differences $(P<0.05)$ were detected between allelic frequencies of genetic groups using the chi-square test. CCAN: Canchim-Red Angus/Nelore; CCCN: Canchim-Caracu/Nelore; CCVN: Canchim-Valdostana/Nelore; CRAN: Caracu-Red Angus/Nelore; CRCN: Caracu-Caracu/Nelore; CRVN; Caracu-Valdostana/Nelore; RACN: Red Angus-Caracu/Nelore.

All polymorphisms were shown to be in Hardy-Weinberg equilibrium $(P>0.05)$; however, significant differences were not observed for genotypic frequencies between genetic groups for any of the SNPs using the chi-square test, as seen in Table 5. Of all the animals genotyped for the FABP3-G/A polymorphism, 111 presented a GG genotype, 81 presented a GA genotype, and 9 exhibited an AA genotype. As for the FABP4-G/C SNP, 123 animals presented the CC genotype, 69 exhibited the GC genotype, and only 9 presented the GG genotype. All 3 genotypes of the FABP4/ Tasl SNP were present in all genetic groups, where 45 animals presented the GG genotype, 116 presented the GA genotype, and 40 presented the AA genotype. 
Table 5. Genotypic frequencies and level of significance for Hardy-Weinberg equilibrium for the polymorphisms FABP3$\mathrm{G} / \mathrm{A}, \mathrm{FABP} 4-\mathrm{G} / \mathrm{C}$, and FABP4/Tasl within each of the seven genetic groups and for the total population of beef cattle.

\begin{tabular}{|c|c|c|c|c|c|c|c|c|c|}
\hline \multirow[t]{2}{*}{ Marker } & \multirow[t]{2}{*}{ Genotype } & \multicolumn{7}{|c|}{ Genetic group } & \multirow[t]{2}{*}{ Total $(\mathrm{N}=201)$} \\
\hline & & $\begin{array}{c}\text { CCAN } \\
(N=26)\end{array}$ & $\begin{array}{c}\text { CCCN } \\
(\mathrm{N}=32)\end{array}$ & $\begin{array}{c}\text { CCVN } \\
(\mathrm{N}=25)\end{array}$ & $\begin{array}{c}\text { CRAN } \\
(\mathrm{N}=29)\end{array}$ & $\begin{array}{c}\text { CRCN } \\
(\mathrm{N}=28)\end{array}$ & $\begin{array}{c}\text { CRVN } \\
(N=26)\end{array}$ & $\begin{array}{c}\text { RACN } \\
(\mathrm{N}=35)\end{array}$ & \\
\hline \multirow[t]{4}{*}{ FABP3-G/A } & GG & 46.1 & 43.8 & 40.0 & 65.5 & 60.7 & 57.7 & 68.6 & 55.2 \\
\hline & GA & 38.5 & 43.7 & 56.0 & 34.5 & 39.3 & 42.3 & 31.4 & 40.3 \\
\hline & AA & 15.4 & 12.5 & 4.0 & 0.0 & 0.0 & 0.0 & 0.0 & 4.5 \\
\hline & HW & 0.745 & 0.985 & 0.358 & 0.533 & 0.433 & 0.392 & 0.544 & \\
\hline \multirow[t]{4}{*}{ FABP4-G/C } & GG & 7.7 & 0.0 & 4.0 & 6.9 & 0.0 & 11.5 & 2.9 & 4.5 \\
\hline & $\mathrm{GC}$ & 23.1 & 9.4 & 56.0 & 41.4 & 46.4 & 46.2 & 25.7 & 34.3 \\
\hline & $\mathrm{CC}$ & 69.2 & 90.6 & 40.0 & 51.7 & 53.6 & 42.3 & 71.4 & 61.2 \\
\hline & HW & 0.423 & 0.962 & 0.358 & 0.982 & 0.278 & 0.995 & 0.985 & \\
\hline \multirow[t]{4}{*}{ FABP4/Tasl } & GG & 23.1 & 12.5 & 28.0 & 24.1 & 21.4 & 34.6 & 17.1 & 22.4 \\
\hline & $\mathrm{GA}$ & 46.2 & 62.5 & 64.0 & 55.2 & 71.4 & 53.9 & 51.4 & 57.7 \\
\hline & AA & 30.8 & 25.0 & 8.0 & 20.7 & 7.1 & 11.5 & 31.4 & 19.9 \\
\hline & HW & 0.936 & 0.312 & 0.249 & 0.853 & 0.053 & 0.782 & 0.957 & \\
\hline
\end{tabular}

CCAN: Canchim-Red Angus/Nelore; CCCN: Canchim-Caracu/Nelore; CCVN: Canchim-Valdostana/Nelore; CRAN: Caracu-Red Angus/Nelore; CRCN: Caracu-Caracu/Nelore; CRVN; Caracu-Valdostana/Nelore; RACN: Red AngusCaracu/Nelore. HW: level of significance of Hardy-Weinberg equilibrium at the $5 \%$ level.

The results of the association study showed a significant effect between FABP3-G/A genotypes and REA $(P=0.035$ ) (Table 6$)$ and the REA/HCW ratio $(P=0.025$; Table 7$)$. In both cases, the AA genotype presented the highest phenotypic value; however, it only differed statistically from the heterozygous GA genotype. On the other hand, significant association was not observed between FABP4-G/C genotypes and any of the observed traits.

A significant effect was also observed between FABP4/Tasl genotypes and meat texture $(P=0.053)$ and marbling $(P=0.052)$ (Table 6). The AA genotype presented the highest scores for meat texture, even though average scores were statistically equivalent to those for the $G G$ genotype. In contrast, heterozygous (GA) animals presented the highest scores for marbling.

Table 6. Significance $(P)$ and mean \pm standard error for phenotypic traits analyzed for the FABP3-G/A, FABP4-G/C, and FABP4/TasI SNP genotypes in beef cattle.

\begin{tabular}{|c|c|c|c|c|c|c|c|c|c|c|}
\hline \multirow[t]{2}{*}{ Marker } & \multicolumn{10}{|c|}{ Variable } \\
\hline & DCONF (days) & $\mathrm{SW}(\mathrm{kg})$ & $\mathrm{HCW}(\mathrm{kg})$ & $\mathrm{HCY}(\%)$ & PHYSMAT (score) & TEXT (score) & $\mathrm{BF}(\mathrm{mm})$ & $\operatorname{REA}\left(\mathrm{cm}^{2}\right)$ & MARB (escore) & $\mathrm{SF}(\mathrm{kg})$ \\
\hline FABP3-G/A & $P=0.368$ & $P=0.384$ & $P=0.301$ & $P=0.450$ & $P=0.967$ & $P=0.370$ & $P=0.098$ & ${ }^{*} \mathrm{P}=0.035$ & $P=0.545$ & $P=0.792$ \\
\hline GG & $136.50 \pm 2.92$ & $403.58 \pm 4.92$ & $221.62 \pm 2.96$ & $54.71 \pm 0.23$ & $14.04 \pm 0.09$ & $4.52 \pm 0.06$ & 0.27 & $62.15 \pm 1.13^{\text {ab }}$ & .37 & 0.27 \\
\hline GA & $1.16 \pm 0.02$ & $409.70 \pm 5.23$ & 224.5 & 54.6 & 14.06 & 4.5 & & $1.19^{\mathrm{a}}$ & & .28 \\
\hline $\mathrm{AA}$ & $1.08 \pm 0.06$ & $417.31 \pm 13.64$ & $233.04 \pm 8.15$ & $55.41 \pm 0.64$ & $14.03 \pm 0.23$ & $4.33 \pm 0.16$ & $4.21 \pm 0.74$ & $67.62 \pm 3.05^{b}$ & $6.69 \pm 1.01$ & $5.60 \pm 0.74$ \\
\hline FABP4-G/C & $P=0.609$ & $P=0.866$ & $P=0.804$ & $P=0.295$ & $P=0.646$ & $P=0.573$ & $P=0.985$ & $P=0.881$ & $P=0.610$ & $P=0.589$ \\
\hline GG & $139.93 \pm 7.64$ & $401.15 \pm 12.91$ & $218.26 \pm 7.72$ & $53.88 \pm 0.61$ & $4.13 \pm 0.23$ & $4.41 \pm 0.16$ & $5.21 \pm 0.75$ & $59.99 \pm 3.11$ & $5.78 \pm 1.01$ & $6.41 \pm 0.74$ \\
\hline GC & $134.28 \pm 3.28$ & $405.66 \pm 5.55$ & 223.43 & $54.84 \pm$ & 0.10 & 4.56 & $5.33 \pm 0.31$ & 1.29 & 0.42 & $5.68 \pm 0.30$ \\
\hline $\mathrm{CC}$ & 137.17 & 407.59 & 223.3 & 54.6 & & & & & & $5.63 \pm 0.27$ \\
\hline FABP4/Tasl & $P=0$ & $P=$ & $P=0$ & P & $P=0$ & ${ }^{*} P=0$ & $P=$ & $P=0$. & ${ }^{*} \mathrm{P}=0.052$ & $P=0.943$ \\
\hline GG & 136.93 & 401.19 & 220.46 & 54.53 & & & & & $=0.47^{\mathrm{ab}}$ & $5.62 \pm 0.35$ \\
\hline $\mathrm{GA}$ & & $404.67 \pm$ & $222.88=$ & & & & & 61. & & $5.70 \pm 0.28$ \\
\hline AA & $135.02 \pm 3.95$ & $415.75 \pm 6.61$ & $226.32 \pm 4.03$ & $54.51 \pm 0.32$ & $13.99 \pm 0.11$ & $4.64 \pm 0.07^{\mathrm{a}}$ & $5.37 \pm 0.37$ & $60.88 \pm 1.51$ & $6.02 \pm 0.49^{\mathrm{b}}$ & $5.77 \pm 0.36$ \\
\hline
\end{tabular}

DCONF = Days in confinement to reach $5 \mathrm{~mm}$ of back fat; $\mathrm{SW}=$ slaughter weight; $\mathrm{HCW}=$ hot carcass weight; $\mathrm{HCY}=$ hot carcass yield; PHYSMAT = physiological maturity (scale from 1 to 15 points split into classes $A$ through $E$ and in subclasses = lower, average, higher; $1=$ older animal and $15=$ youngest animal); TEXT = meat texture (scale from 1 to 5 points, $1=$ rough and $5=$ fine); $B F=$ back fat thickness at the dorsal lumbar region on the carcass; $R E A=$ rib eye area measured on the carcass; MARB $=$ marbling (values from 1 to 18 , where 1 to $3=$ traces, 4 to $6=$ light, 7 to $9=$ low, 10 to 12 = average, 13 to $15=$ high, and 16 to 18 = abundant); SF = shear force. ${ }^{*} P \leq 0.05$. ${ }^{a, b}$-Values in the same column followed by different letters differ among themselves. 
Table 7. Significance $(P)$ and mean \pm standard error of the ratio between rib eye area and hot carcass weight (REA/HCW), distribution of back fat on carcass (BFCARC), and gain in back fat per day of confinement (BF/D) for genotypes for markers FABP3-G/A, FABP4-G/C, and FABP4/Tasl.

\begin{tabular}{lccc}
\hline Marker & & Variable & BF/D $\left(\mathrm{cm}^{2} / \mathrm{day}\right)$ \\
\cline { 2 - 4 } & REA/HCW $\left(\mathrm{cm}^{2} / \mathrm{kg}\right)$ & BFCARC & $\mathrm{P}=0.143$ \\
\hline FABP3-G/A & ${ }^{*} \mathrm{P}=0.025$ & $\mathrm{P}=0.061$ & $4.44 \pm 0.29$ \\
GG & $0.28 \pm 0.004^{\mathrm{a}}$ & $2.66 \pm 0.14$ & $4.05 \pm 0.31$ \\
GA & $0.27 \pm 0.004^{\mathrm{b}}$ & $2.38 \pm 0.15$ & $3.04 \pm 0.79$ \\
AA & $0.29 \pm 0.01^{\mathrm{a}}$ & $1.98 \pm 0.38$ & $\mathrm{P}=0.801$ \\
FABP4-G/C & $\mathrm{P}=0.876$ & $2.61 \pm 0.971$ & $3.80 \pm 0.80$ \\
GG & $0.28 \pm 0.01$ & $2.51 \pm 0.16$ & $4.33 \pm 0.33$ \\
GC & $0.28 \pm 0.004$ & $2.52 \pm 0.14$ & $4.23 \pm 0.29$ \\
CC & $0.28 \pm 0.004$ & $\mathrm{P}=0.930$ & $\mathrm{P}=0.940$ \\
FABP4/Tasl & $\mathrm{P}=0.093$ & $2.56 \pm 0.18$ & $4.14 \pm 0.37$ \\
GG & $0.28 \pm 0.005$ & $2.53 \pm 0.15$ & $4.28 \pm 0.31$ \\
GA & $0.28 \pm 0.004$ & $2.47 \pm 0.19$ & $4.27 \pm 0.39$ \\
AA & $0.27 \pm 0.005$ & & \\
\hline
\end{tabular}

${ }^{*} \mathrm{P} \leq 0.05$. ${ }^{a, b-V}-$ Values in the same column followed by different letters differ among themselves.

When a markers genotype presented significant results $(P \leq 0.05)$, allelic substitution was estimated by substituting the effect of the genotype in the statistical model by covariates representing the quantity of the least frequent allele $(0,1$, and 2$)$, as shown in Table 8 . This was made possible because alleles (but not genotypes) are transmitted to descendants; therefore, one can indicate an associated value for each allelic variant held by the individual (Falconer and Mackay, 1996). This analysis verified that the $\mathrm{G}$ allele of the FABP3-G/A SNP leads to a reduction in rib eye area while the $A$ allele of the FABP4/TasI SNP reduces marbling scores and increases texture. Nevertheless, these effects were small, and thus, no significant associations were observed in this analysis.

Table 8. Mean effect of allelic substitution \pm standard error for polymorphisms with significant associations to carcass traits in beef cattle.

\begin{tabular}{lclcl}
\hline Marker & Allele & Variable & Effect of allelic substitution & P \\
\hline FABP3-G/A & G & REA $\left(\mathrm{cm}^{2}\right)$ & $-0.11 \pm 1.06$ & 0.9180 \\
FABP3-G/A & G & REA/HCW & $-0.004 \pm 0.003$ & 0.2766 \\
FABP4/Tasl & A & TEXT & $0.04 \pm 0.05$ & 0.3946 \\
FABP4/Tasl & A & MARB (score) & $-0.11 \pm 0.30$ & 0.7252 \\
\hline
\end{tabular}

TEXT = meat texture (scale from 1 to 5 points, $1=$ rough and $5=$ fine); REA = rib eye area on carcass; MARB = marbling (values from 1 to 18 , where 1 to $3=$ traces, 4 to $6=$ light, 7 to $9=$ low, 10 to $12=$ average, 13 to $15=$ high, and 16 to 18 = abundant); REA/HCW = ratio between rib eye area and hot carcass weight.

\section{DISCUSSION}

\section{SNP identification}

Variants in FABP3 have sparked interest because this gene is responsible for intracellular fatty acid availability, mobilization, and usage, mostly towards oxidation in the mitochondria (Glatz and van der Vusse, 1996; Glatz et al., 2003; Gardan et al., 2007). In swine, this gene has been considered a candidate for fat deposition traits; however, effects have been contradictory (Nechtelberger et al., 2001; Chmurzynska, 2006). Few studies have been published to date and results are equally inconsistent (Cho et al., 2008). Cho et al. (2008) identified 5 SNPs in FABP3, 
only one of which was found in the present work (rs210186725). This SNP, however, did not present significant association with fat deposition traits in the previous study.

As for FABP4, of the 9 identified polymorphisms, SNP rs110383592 is noteworthy for having been studied by various authors in animals of different breeds (Cho et al., 2008; Barendse et al., 2009; Oh et al., 2012). Barendse et al. (2009) found this SNP to be associated with intramuscular fat deposition (marbling) in a population of Australian cattle. According to the authors, this SNP is found within a splice site between the third exon and the third intron, which makes it a functional polymorphism. On the other hand, this association has not been consistent among other studies. Oh et al. (2012) was unable to find significant association between this SNP and fat deposition traits, although it was shown to be associated to saturated and unsaturated fatty acid composition in the Hanwoo breed of cattle.

Most of the SNPs identified in both FABP3 and FABP4 were located in intronic regions. Nevertheless, several intronic markers have been described in the literature and shown to be associated with meat and carcass quality traits in beef cattle (White et al., 2005; Schenkel et al., 2006; Sherman et al., 2008).

\section{Genotyping and association with phenotypic traits}

For the FABP3-G/A polymorphism, the least frequent AA genotype was only observed in groups in which Canchim represented the terminal breed used for crossbreeding: CCAN $(N=4)$, CCCN $(N=4)$, and CCVN $(N=1)$. The A allele is apparently exclusive to zebuine breeds since Canchim sires (which hold a portion of zebuine genes: $5 / 8$ Charolês and $3 / 8$ zebu) were probably the only ones to transmit the allele to offspring. Considering that this was the first description of this SNP in the literature, new studies are needed to confirm this hypothesis.

Most previous association studies between SNPs in FABP3 and traits of economic interest were carried out in swine (Gerbens et al., 1999; Chmurzynska et al., 2007); however, these results differ from those in the current study since all associations were made with either intramuscular or carcass distribution of back fat. Since the FABP3-G/A SNP is present in a gene involved in fat deposition and this is the first study to analyze this polymorphism, further studies are needed to validate these findings in different populations.

As for the FABP4-G/C SNP, the only genetic groups that did not present the GG genotype were CCCN and CRCN (Table 5). Oh et al. (2012) genotyped this same SNP in the Hanwoo breed of Korean cattle and found genotypic frequencies of 36.3, 47.7, and 16\% for GG, GC, and CC, respectively, and they found the $C$ allele to be the least frequent (44\%). In Australian cattle from seven distinct breeds (Angus, Brahman, Belmont Red, Hereford, Murray Grey, Santa Gertrudis, and Shorthorn), Barendse et al. (2009) observed C allele frequencies ranging from 45 (Angus) to 85\% (Brahman). In contrast to Oh et al. (2012) and Barendse et al. (2009), the lower frequency of the $\mathrm{G}$ allele observed in this study may indicate that this allele is either being introduced or removed from the studied population.

The results for the FABP4-G/C genotype and the traits studied herein are in accordance with Oh et al. (2012) who did not show association between this SNP and fat deposition traits in cattle of the Hanwoo breed, although he did observe an association with fatty acid composition. However, Barendse et al. (2009), found the SNP to be associated to intramuscular fat deposition (marbling) in different Australian bovine breeds.

For the FABP4/TasI SNP we were unable to determine if this genotypic distribution was 
present in other populations due to the lack of information about this SNP in the literature, nor was it possible to verify whether the association results corroborate those for other populations.

The small effects observed in this study are common due to the quantitative nature of these variables, which are generally controlled by many genes of lesser individual effect and influenced by environmental factors (Andersson, 2001). According to Barendse et al. (2009), the effect of FABP4 is small, which hinders the ability to detect it. Cho et al. (2008) also argue that since statistical power to detect significant associations for both FABP4 and FABP3 are low, an alternative approach to confirm suggestive associations would be replication in larger populations with different breeds and larger phenotypic variation. Technologies are available that detect thousands of SNPs simultaneously with a reduction in cost and time. Therefore, it is possible to include information from thousands of SNPs associated with many traits of interest in the prediction of the genetic value of each animal, promoting significant advances in animal production.

The genes analyzed herein (FABP3 and FABP4) appear to contribute to the development of general carcass traits, albeit through a small effect. Even though they may not be considered major genes in the development of these phenotypes, they may be used in haplotype studies or within a panel of markers whose cumulative effects may better explain the phenotypic variation observed between breeds and animals, which would lead to a more powerful analysis and enhance the accuracy of genetic prediction.

\section{Conflicts of interest}

The authors declare no conflict of interest.

\section{ACKNOWLEDGMENTS}

We acknowledge EMBRAPA and the Conselho Nacional de Desenvolvimento Científico e Tecnológico (CNPq) for financing the project as well as Coordenação de Aperfeiçoamento de Pessoal de Nível Superior (CAPES) and the Universidade Estadual do Mato Grosso do Sul (UEMS) for student grants afforded.

\section{REFERENCES}

Andersson L (2001). Genetic dissection of phenotypic diversity in farm animals. Nature 2: 130-138.

Barendse W (1999). Assessing lipid metabolism. Patent, International Publication number: WO 99/23248. World International Property Organization.

Barendse W, Bunch RJ, Thomas MB and Harrison BE (2009). A splice site single nucleotide polymorphism of the fatty acid binding protein 4 gene appears to be associated with intramuscular fat deposition in longissimus muscle in Australian cattle. Anim. Genet. 40: 770-773.

Buchanan FC, Fitzsimmons CJ, Van Kessel AG, Thue TD, et al. (2002). Association of a missense mutation in the bovine leptin gene with carcass fat content and leptin mRNA levels. Genet. Sel. Evol. 34: 105-116.

Chmurzynska A (2006). The multigene family of fatty acid-binding proteins (FABPs): function, structure and polymorphism. J. Appl. Genet. 47: 39-48.

Chmurzynska A, Szydlowski M, Stachowiak M, Stankiewicz M, et al. (2007). Association of a new SNP in promoter region of the porcine $F A B P 3$ gene with fatness traits in a Polish synthetic line. Anim. Biotechnol. 18: 37-44.

Cho S, Park TS, Yoon DH, Cheong HS, et al. (2008). Identification of genetic polymorphisms in FABP3 and FABP4 and putative association with back fat thickness in Korean native cattle. BMB Rep. 41: 29-34.

Davis GP and DeNise SK (1998). The impact of genetic markers on selection. J. Anim. Sci. 76: 2331-2339.

Euclides Filho K (1999). Melhoramento genético animal no Brasil: fundamentos, história e importância. Série Documentos 
Embrapa Gado de Corte, 75, 63.

Falconer DS and Mackay TFC (1996). Introduction to quantitative genetics. 4th edn. The Longman Group Ltd., Edinburgh.

Ferraz JBS and Eler JP (2010). Parceria público x privada no desenvolvimento de pesquisa em melhoramento genético animal. R. Bras. Zootec. 39: 216-222.

Gardan D, Louveau I and Gondret F (2007). Adipocyte- and heart-type fatty acid binding proteins are both expressed in subcutaneous and intramuscular porcine (Sus scrofa) adipocytes. Comp. Biochem. Physiol. B Biochem. Mol. Biol. 148: 14-19.

Gerbens F, van Erp AJ, Harders FL, Verburg FJ, et al. (1999). Effect of genetic variants of the heart fatty acid-binding protein gene on intramuscular fat and performance traits in pigs. J. Anim. Sci. 77: 846-852.

Glatz JF and van der Vusse GJ (1996). Cellular fatty acid-binding proteins: their function and physiological significance. Prog. Lipid Res. 35: 243-282.

Glatz JF, Schaap FG, Binas B, Bonen A, et al. (2003). Cytoplasmic fatty acid-binding protein facilitates fatty acid utilization by skeletal muscle. Acta Physiol. Scand. 178: 367-371.

Hertzel AV, Smith LA, Berg AH, Cline GW, et al. (2006). Lipid metabolism and adipokine levels in fatty acid binding protein null and transgenic mice. Am. J. Physiol. Endocrinol. Metab. 290: E814-823.

Luchiari Filho A (2000). Pecuária da carne bovina. 1st edn. Luchiari Filho, São Paulo.

Menezes LF, Segabinazzi LR, Brondani IL, Restle J, et al. (2009). Silagem de milho e grão de sorgo como suplementos para vacas de descarte terminadas em pastagem cultivada de estação fria. Arq. Bras. Med. Vet. Zootec. 61: 182-189.

Michal JJ, Zhang ZW, Gaskins CT and Jiang Z (2006). The bovine fatty acid binding protein 4 gene is significantly associated with marbling and subcutaneous fat depth in Wagyu x Limousin F2 crosses. Anim. Genet. 37: 400-402.

Muller L (1980). Normas para avaliação de carcaças e concurso de carcaças de novilhos. 1st edn. Universidade Federal de Santa Maria, Santa Maria.

Nechtelberger D, Pires V, Solkner J, Stur I, et al. (2001). Intramuscular fat content and genetic variants at fatty acid-binding protein loci in Austrian pigs. J. Anim. Sci. 79: 2798-2804.

Oh DY, Lee YS, La BM and Yeo JS (2012). Identification of the SNP (single nucleotide polymorphism) for fatty acid composition associated with beef flavor-related FABP4 (fatty acid binding protein 4) in Korean cattle. Asian Australas. J. Anim. Sci. 25: 913-920.

Regitano LCA and Coutinho LL (2001). Biologia molecular aplicada à produção animal. Embrapa Informação Tecnológica, Brasília.

Roy R, Calvo JH, Hayes H, Rodellar C, et al. (2003). Fine mapping of the bovine heart fatty acid-binding protein gene (FABP3) to BTA2q45 by fluorescence in situ hybridization and radiation hybrid mapping. Anim. Genet. 34: 466-467.

SAS Institute (2003). SAS/STAT: user's guide. Version 9.1. Cary, North Carolina.

Schenkel FS, Miller SP, Jiang Z, Mandell IB, et al. (2006). Association of a single nucleotide polymorphism in the calpastatin gene with carcass and meat quality traits of beef cattle. J. Anim. Sci. 84: 291-299.

Sherman EL, Nkrumah JD, Murdoch BM, Li C, et al. (2008). Polymorphisms and haplotypes in the bovine neuropeptide Y, growth hormone receptor, ghrelin, insulin-like growth factor 2, and uncoupling proteins 2 and 3 genes and their associations with measures of growth, performance, feed efficiency, and carcass merit in beef cattle. J. Anim. Sci. 86: 1-16.

Specht B, Bartetzko N, Hohoff C, Kuhl H, et al. (1996). Mammary derived growth inhibitor is not a distinct protein but a mix of heart-type and adipocyte-type fatty acid binding protein. J. Biol. Chem. 271: 19943-19949.

Thaller G, Kühn C, Winter A, Ewald G, et al. (2003). DGAT1, a new positional and functional candidate gene for intramuscular fat deposition in cattle. Anim. Genet. 34: 354-357.

Van Eenennaam A (2009). Marker assisted selection. University of California. Available at [http://animalscience.ucdavis.edu/ animalbiotech/Outreach/Marker_Assisted_Selection_in_Beef_Cattle.pdf]. Accessed January 6, 2014.

Veerkamp JH and Maatman RG (1995). Cytoplasmic fatty acid binding proteins: their structures and genes. Prog. Lipid Res. 34: $17-52$.

Weir BS (1996). Genetic data analysis II: methods for discrete population genetic data. 2nd edn. Sinauer Associates, Inc., Massachusetts.

White SN, Casas E, Wheeler TL, Shackelford SD, et al. (2005). A new single nucleotide polymorphism in CAPN1 extends the current tenderness marker test to include cattle of Bos indicus, Bos taurus, and crossbred descent. J. Anim. Sci. 83: 2001-2008 